\title{
Knowledge Management as an Approach to Learning and Instructing Sector University Students in Post-Soviet Professional Education
}

\author{
Irina S. Volegzhanina ${ }^{1}$, Svetlana V. Chusovlyanova ${ }^{2}$, Vladimir A. Adolf ${ }^{3}$, Ekaterina S. Bykadorova ${ }^{4}$, \\ Elena N. Belova ${ }^{5}$
}

\begin{abstract}
The relevance of the study depends on addressing to the issue of knowledge management in learning and instructing students of post-Soviet sector universities. In this regard, the article is intended to reveal the nature of knowledge management approach compared to the knowledge-based one predominated in Soviet education. The flagship approach of this study is the systemic-activity approach to explain knowledge management advantages for learning and instructing social disciplines in sector universities. The relevant literature is reviewed to show evolution of approaches. It is stated that knowledge reflecting specificity of an industry may be defined as industry-oriented and can be represented by a new international web standard (ontology). To determine significant factors for knowledge absorption with the proposed approach an experiment was conducted. The results prove the didactic potential of ontologies, so the knowledge management approach is considered promising. This article may be of practical interest for professors of sector universities.
\end{abstract}

Keywords: approach, sector university, knowledge management, factor, ontology.

\section{Introduction}

It seems clear that the amount and quality of knowledge that students absorb during their university studies have an impact on quality of education they receive. This is particularly significant in case of universities supplying sectors of Russian economy with a workforce of required competencies in knowledge and skills. The quality of education received by sector university leavers and their willingness to pursue a carrier in a particular industry could determine whether they are competitive in the global industrial markets. As an essential part of the "willingness $=$ aspiration + knowledge + skills" equation, knowledge accounts for all the

\footnotetext{
${ }^{1}$ Assoc. Prof., Candidate of Pedagogy, Siberian Transport University, erarcher@mail.ru

${ }^{2}$ Assoc. Prof., Candidate of Sociology, Siberian Transport University, c10506@yandex.ru

${ }^{3}$ Prof., Doctor of Pedagogy, Krasnoyarsk State Pedagogical University named after V.P. Astafiev, adolf@kspu.ru

${ }^{4}$ Assoc. Prof., Candidate of Pedagogy, Siberian Transport University, bykadorova_es@mail.ru

${ }^{5}$ Assoc. Prof., Candidate of Pedagogy, Krasnoyarsk State Pedagogical University named after V.P. Astafiev, belovaen@list.ru
} 
components of sector workforce education such as theoretical courses, practical training and corporate value navigating (Adolf et al., 2011; Kilinç et al., 2016).

Focusing on transferring a parcel of knowledge from an instructor to students for further knowledge accumulation was illustrative of Soviet professional education. The technological break-through caused by onrush of information and communication technologies has rendered this approach ineffective. Mining of information that may be useful has become problematic for students and resulted in expanded learning time and rather poor knowledge absorption. Under current socio-economic conditions, "natural" knowledge management in education has exhausted its potential and required information technology solutions.

In this article, we consider knowledge as a data entity that is a result of cognitive activity of an agent (human or artificial) represented in a well-structured form and "stored in memory in a way that makes it useful for application and task performance" (De Jong \& Ferguson-Hessler, 1996, p. 107). This data entity has a potential to develop within an environment that is intelligence. Due to an agent is an entity that must have a goal to act, it uses knowledge as a main resource to achieve the required goal in a certain space. If an agent is a learning agent, it has an ability to generate new knowledge applying to already absorbed knowledge both independently and with an instructor (a human or a computer).

This understanding of knowledge described in literature on expert knowledge representation (Guillou, 2007; Sim 2015) seems to be useful for capturing didactic potential of ontologies as a new international web-standard for knowledge representation (ISO/IEC 200161:2014). This standard has differentiated Virtual Learning Environment 2.0 (Chua \& Tay, 2011; Bykadorova et al., 2014) with hypertext knowledge representation and 3.0 based on Semantic Web technologies (Hussain, 2013).

\section{Literature Review}

\section{Knowledge-based, competency-based and knowledge management approaches}

A knowledge-based approach predominated in Soviet education and considered scientific knowledge as intellectual wealth of a person. Hence, to accumulate knowledge by memorising theoretical facts for their further reproducing was the key objective for students. Pedagogical studies paid much attention to knowledge absorption (Bespalko, 1989, Ginecinskij, 1989; Nurminskij \& Gladysheva, 1991, Poljakova, 1978). However, the knowledge resource of a student remained poor-structured and unproductive for decision-making. 
Changes in post-Soviet society resulted in replacement of this approach by the competency-based one (Ivanova, 2007). After 1990s within the Knowledge Economy development, the term "knowledge management" has been introduced. It refers to a multidisciplinary approach to achieving organisational objectives by making the best use of knowledge (Introduction to Knowledge Management, 2007). Nowadays the value of knowledge management approach to university education is widely discussing among Russian researchers. Some studies consider a university as an enterprise where all concepts and principles of corporate knowledge management could be applied the same way (Kudinov, 2010, Dorokhova, 2015). Others recognise it effective to improve academic performance (Andrianova, 2013, Lishilin et al., 2015).

Due to a wide variety of knowledge management definitions in education, we consider important to distinguish the following concepts: knowledge management is a strategy focused on corporate objectives such as improved performance, competitive advantage and continuous improvement (Gupta \& Sushil, 2004); knowledge management is a process of creating, using, sharing and transferring knowledge based on the knowledge life cycle (Girard \& Girard, 2015). Industry-related knowledge

In the literature on learning and instructing, different types of knowledge are described and many terms to identify them are used. De Jong and Ferguson-Hessler (1996) explained complex nature of a knowledge base of a person and constructed a knowledge-in-use matrix relevant for problem solving. This knowledge matrix shows types and qualities of knowledge as its dimensions. Another important conclusion was that all types of knowledge are frequently bound to a domain. Due to this, educational programmes concentrating on general problemsolving are usually less successful compared to domain-specific programmes (De Jong \& Ferguson-Hessler, 1996; Alexander, 2003).

Be knowledge acquired at a university theoretical or practice-oriented it means academic knowledge. This knowledge is adopted and edited for better digestion by students and exists mainly in textual form. Eraut (2004) described it as codified academic knowledge in contrast to codified non-academic knowledge that can be found at workplaces. Thus, transferring and adapting codified knowledge between an industry and a university considers an important issue.

One might assume that all knowledge circulating within a particular industry is industryspecific as well as the knowledge base of a sector university graduate. The National Research 
Council of Canada (2015) interprets industry-related knowledge as a pool of knowledge developing by industry enterprises, businesses, scientific centres and educational establishments. This means that universities could be essential suppliers of knowledge and graduates to some industries in a global knowledge society and economy (Edler, 2003, Leisyte \& Horta 2011, Wright, 2015). The importance of knowledge transfer between universities and a workplace has been described in (Eraut, 2004, Varga \& Parag, 2009, Bellucci \& Pennacchio, 2016). However, only a few researches explain the nature of industry-related knowledge (Pathirage et al., 2008, Mitsuk et al., 2016).

As Eraut (2004) stated, transfer of codified knowledge between education and workplace is a learning process where a person adopts previously absorbed knowledge to a new situation that could be time and effort consuming. As a rule, knowledge adaptation occurs at workplace and may be more or less effective. Early adaptation of codified academic knowledge through the integrative life cycle and storage in the open knowledge resource could reduce time and efforts devoted to its transfer to a workplace. This also could broaden managing knowledge beyond the industry or the university in order they both develop and assess academic knowledge of students through common educational resources. Thus, an industry could employ a workforce with a required level of knowledge.

Finally, the interconnection between an industry and education determines the domainspecific and task dependent nature of industry-related knowledge to be absorbed by sector university students. We have proposed three components in its structure: general professional knowledge, restricted professional knowledge and corporate knowledge (Volegzhanina, 2016). Following Alexander and Judy (1988), the levels of industry-related knowledge include declarative, procedural and conditional knowledge. We have added motivating knowledge or "want-to-know-why" knowledge to this list. This highest level of knowledge relates to personal desire, intrinsic interest and the will to success.

\section{Evaluation of knowledge absorption}

Knowledge is a valuable intellectual resource of a student who uses it for decisionmaking and an indicator of educational progress (Bittman \& Russell, 2016). It is related to both personal efficiency (know-how) and effectiveness (know-what) (Zeleny, 2006), therefore its 
absorption capacity should be sufficiently evaluated. A number of dimensions can be found in Zhi-xiong Xiao (2017), who introduced acquisition of knowledge capacity, digestion of knowledge capacity, knowledge transformation capacity and knowledge utilization capacity to evaluate knowledge absorption process. From the perspective on knowledge-in-use, this means that task performance forms the basis for testing knowledge in learning and instructing.

It is also advisory to distinguish surface-level and deep-level knowledge (De Jong \& Ferguson-Hessler, 1996). Eraut (2004) concluded that education at most provides surface knowledge, which is well supported by textbooks. Deep knowledge means to know how to use the acquired knowledge in a range of possible situations and "support for such learning is minimal" (Eraut, 2004, p. 15).

The above listed dimensions can also allow for evaluating how efficient educational resources using by students are. We will consider an educational resource as a certain managerial instrument for didactic (learning and instructing) purposes. To evaluate whether an educational resource effective, one should calculate cost, time and efforts for its development.

In the literature on school and university education, a great number of didactic instruments have been described and the results of their implementation into practice have been evaluated (Bykadorova \& Skibitsky, 2009; Kybartaite et al., 2010; Diaz Redondo, 2012; Jung, 2013; Hornos et al., 2012; Uzun, 2012, Asoodar et al. 2014; Grammes \& Açıkalın, 2016; Tarman \& Acun, 2010; Tarman, 2016). All of them to any extent allow for knowledge absorption and improving academic performance (Demirhan \& Yücel, 2016). Experience has proven that their effectiveness depends on many factors and conditions and it is difficult to get reliable understanding which of them are significant for managing knowledge to be reproduced in skills. User studies may help to evaluate the potential of a proposed approach.

\section{Materials and Methods}

\section{Aim, tasks and method}

The aim of the experiment is to determine the factors that are significant for absorption of knowledge by students of a sector university (as an example of a railway university). With this in view, the following questions are asked to generate a hypothesis: Is focus of academic knowledge on a particular industry significant? Is a type of knowledge holder significant? Is a way to transfer knowledge significant? Is a student's major significant? Is a form of knowledge representation in educational resources significant? 
To achieve the goal we have established the following tasks: to design proper didactic materials; to define the requirements for the participants; to define the dimensions to evaluate knowledge absorption; to describe the procedure of experiment; to analyse the results obtained.

As a method to evaluate the didactic potential of ontological content, we applied to student performance tests and a questionnaire survey. This experimental work is an ascertaining experiment of more comprehensive study applying to the issue of knowledge co-management within the "sector - sector university" system.

\section{Materials}

We tested our hypothesis in the English for Professional Purposes Course that is compulsory for all students in Russian railway universities. It is practice-oriented and allows for assessing student performance in absorption of knowledge within a single course. It provides integration of social and engineering disciplines therefore the level of knowledge absorption (surface or deep) can be assessed as well. Common methods of teaching English as a second language makes it possible to assess linguistic knowledge and communication skills separately through knowledge-oriented and skills-oriented exercises.

As didactic materials, we used the English for Railways Study Package (ERSP) (Volegzhanina \& Chusovlyanova, 2016). Its framework consists of the two interconnected blocks. The inner block has the ERSP modules: course books in a text format (.pdf), exercise programme files for student self-work in a hypertext format, test programme files in a hypertext format and vocabulary in both formats. The outer block comprises the guidance for students and instructors, the list of organisational conditions, the database.

\section{Participants}

The experiment to be described was performed on 186 participants - engineering and business students of a railway university. The requirements for the participants have been defined as follows: they had to be first and second year students of Bachelor or Specialists Programmes (on average 20 years old) and learn English as a second language. At least preintermediate skills in General English were required. The participants were divided into two groups - an experimental group - group 1 (93 students) and a control one - group 2 (78 students). Students in group 1 used printed English course books supported by audio and video materials. Students in group 2 used the ERSP. Testing was conducted with the ERSP test programme files. 
We also conducted two questionnaire surveys in the different phases of an experiment. 160 students of a railway university participated in the first questionnaire survey and 270 students of three sector universities (railway, information and communication, building and construction) participated in the second questionnaire survey.

\section{Dimensions}

As a first dimension, student performance was chosen. We used knowledge-oriented and skills-oriented tests to receive a feedback about absorbing knowledge by students and understanding whether there was a dependency of knowledge and communication skills. Progress tests assessed the overall result of learning. As a second dimension, time of student selfwork study was taken to indicate progress in a learning time. As a third dimension, we looked at the ERSP advantages to see whether the students would mention a content representation format. The questionnaire that the participants filled in after the experiment contained questions about advantages and disadvantages of learning with the ERSP. To specify the choice of participants about the preferable format of knowledge representation we conducted a supplementary questionnaire survey.

\section{Procedure}

The experiment started in December 2013 and completed in May 2017. The overall procedure consisted of four phases: Instruction Phase, Learning Phase, Testing Phase and Questionnaire.

For the instruction phase, the participant received a file with the User Guidance that explained how to use the ERSP programme modules for self-work study and testing. This is also required a preparatory training of instructors. Because the students and the instructors experienced an adaptation period of approximately one month, the course team provided their methodological assistance.

During the learning phase, students in group 1 use .pdf course book files and exercise programme files available in a university computer room and through LCD Moodle and Dropbox cloud storage. The students combined two ways of learning: "face-to-face" with an instructor and self-work study with the ERSP online exercise programme files. To gain student knowledge in professional vocabulary, instructors asked the participants to learn the key word lists by heart. During the testing phase, student performance in their self-work was tested. The students in the experimental group performed their self-work in the exercise programme files in a hypertext 
format. Testing of their works was automatic and the results were sent to the database. The students in the control group worked with the exercise book files and their works were checked by the instructors.

Knowledge and skills were checked separately. We used progress tests to assess student performance for understanding their communication competence level. To evaluate the student performance results the following scale matching the international assessment scale for learner performance results was accepted (see Table 1).

Table 1

Assessment scale for student performance results

\begin{tabular}{lll}
\hline \multicolumn{1}{c}{ Mark } & \multicolumn{1}{c}{ Score } & \multicolumn{1}{c}{ Level } \\
\hline A (Excellent) & $95-100 \%$ & High \\
\hline B (Good) & $81-94 \%$ & Adequate \\
\hline C (Satisfactory) & $70-80 \%$ & Threshold \\
\hline D (Poor) & $<70 \%$ & Unacceptable \\
\hline
\end{tabular}

Testing was also automatic. Test evaluation reports were sent to the monitoring database upon completion of student self-study work and progress tests. In this way, it was also investigated how much time the participants needed to learn during their self-work.

Finally, the students received a questionnaire form inquiring about their experience during the experiment. They were asked to list the advantages and disadvantages of the ERSP. To investigate the preferable form of knowledge representation in educational resources another questionnaire survey among sector-university students was conducted.

\section{Results and Discussion}

The results of the experiment allow for comparing didactic instruments to manage knowledge of sector university students in a learning process on the basis of student performance results, time required by the participants, and answers they gave in the questionnaires. It also had to be evaluated whether the format of content representation in educational resources was a significant factor or not.

\section{Student performance results}

Student performance results indicated in their practice work automated reports are given in Table 2. 171 works were analysed in total.

Table 2 
Student performance results (self-study work) 2013-2017

\begin{tabular}{|c|c|c|c|c|c|c|c|c|}
\hline \multirow[t]{3}{*}{$\begin{array}{c}\text { Student } \\
\text { Group }\end{array}$} & \multirow[t]{3}{*}{$\begin{array}{l}\text { Number } \\
\text { of works }\end{array}$} & \multirow{3}{*}{$\begin{array}{c}\text { Number } \\
\text { of works } \\
\text { at A-C } \\
\text { level }\end{array}$} & \multicolumn{3}{|c|}{$\begin{array}{l}\text { Knowledge-oriented } \\
\text { works }\end{array}$} & \multicolumn{3}{|c|}{ Skills-oriented works } \\
\hline & & & \multicolumn{2}{|l|}{ Score } & \multirow[t]{2}{*}{ Level } & \multicolumn{2}{|l|}{ Score } & \multirow[t]{2}{*}{ Level } \\
\hline & & & $\begin{array}{c}\text { Number of } \\
\text { works }\end{array}$ & $\%$ & & $\begin{array}{c}\text { Number } \\
\text { of } \\
\text { works }\end{array}$ & $\%$ & \\
\hline group 1 & 93 & 63 & 55 & 59 & $\overline{\mathrm{A}-\mathrm{C}}$ & 41 & 44 & $\overline{\mathrm{A}-\mathrm{C}}$ \\
\hline group 2 & 78 & 53 & 43 & 55 & $\overline{A-C}$ & 29 & 37 & $\mathrm{~A}-\mathrm{C}$ \\
\hline Total & 171 & & 149 & & & & & \\
\hline $\begin{array}{l}\text { Difference } \\
\text { in rates }\end{array}$ & & & 23 & $+4 \%$ & & & $+17 \%$ & \\
\hline
\end{tabular}

The works were divided into knowledge-oriented (vocabulary) and sills-oriented (listening, reading and writing). The results were assessed automatically. As Table 2 shows, group 1 performed better than group 2 did.

Sixty-three students made their self works at A-C levels that made 67\%. Fifty-three students in group 2 performed their self-work at A-C level that also made 67\%. However, it is not a considerable and statistically significant difference. To evaluate the significance of the results we use the criterion $\chi^{2}$ which was calculated by

$$
\chi^{2}=\sum_{i=1}^{r} \sum_{j=1}^{c} \frac{\left(O_{i j}-E_{i j}\right)^{2}}{E_{i j}} .
$$

The results of calculations are given in Tables 3 and 4 .

Table 3

Criteria for evaluating the significance of differences depending on the performed works

\begin{tabular}{lcc}
\hline Criterion & Value & Significance \\
\hline Chi-square & 0.001 & $\mathrm{p}>0,05$ \\
\hline $\begin{array}{l}\text { Chi-square test with Yates' } \\
\text { correction }\end{array}$ & 0.018 & $\mathrm{p}>0,05$ \\
\hline & The minimum value - 25.09 \\
\hline
\end{tabular}

Table 4

Criteria for evaluating the power of connection between the representation type of educational resource and performance level 


\begin{tabular}{ccc}
\hline Criterion & Value & Power of Connection \\
\hline Pearson's contingency coefficient & 0.002 & irrelevant \\
\hline $\begin{array}{c}\text { Normalized value of the Pearson correlation } \\
\text { coefficient }\end{array}$ & 0.003 & irrelevant \\
\hline
\end{tabular}

But, if we look more closely at the results of performing knowledge-oriented and skillsoriented works we may notice greater difference. Fifty-five knowledge-oriented works at group 1 were performed at A-C level, that makes $59 \%$. Students in group 2 performed 43 works at A-C level that makes 55\%. By percentage, the first group shows a little better result. As for skillsoriented works there are bigger differences. $59 \%$ of knowledge-oriented works were performed at the A-C level in case of group 1 and $55 \%$ in case of group 2 . Thus, the result in the experimental group was on average 4 points better than the result in the control group.

Forty-four per cent of skills oriented works were performed at A-C level in case of group 1 and $37 \%$ in case of group 2. Thus, the result in the experimental group was on average 14 points better than the result in the control group. This is not a considerable and statistically significant difference. Because the critical value is 0.576, while $\chi^{2}$ at significance level is 0.070 , which is $>0.05$.

According to these results, one can say that knowledge-oriented works were performed better by both groups of participants compared to skills-oriented works. The power of connection is irrelevant, so, we may see a poor dependence between knowledge and skills. The reason might be that knowledge of vocabulary or grammar structures is mainly surface which store in students' memory as a copy of external information. For understanding the difference between deep-level and surface-level knowledge see, e.g., de Jong and Ferguson-Hessler, 1996.

Table 5 shows the Progress Tests results.

Table 5

Student performance results (Progress Test) 2013-2017

\begin{tabular}{ccccccc}
\hline Student Group & $\begin{array}{c}\text { Number } \\
\text { of works }\end{array}$ & $\begin{array}{c}\text { Score, } \\
\%\end{array}$ & \multicolumn{3}{c}{$\begin{array}{c}\text { Level (communication } \\
\text { competence) / number of works }\end{array}$} \\
\cline { 3 - 6 } & & & A & B & C & D \\
\hline group 1 & 93 & 86 & 26 & 17 & 25 & 10 \\
\hline group 2 & 78 & 84 & 16 & 22 & 28 & 12 \\
\hline
\end{tabular}




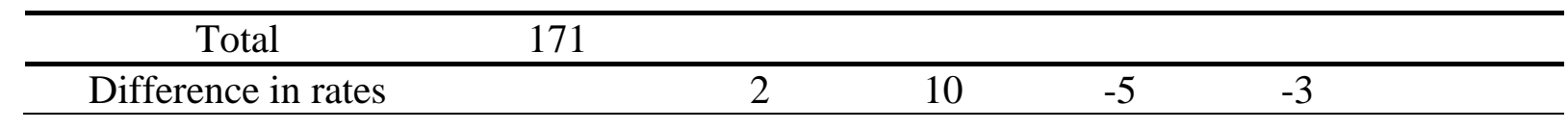

To evaluate the significance of the results we also use the criterion $\chi^{2}$. The criterion $\chi^{2}$ is 2.394. So, critical value $\chi^{2}$ at significance level $p<0.05$ is 5.991. Thus, there is no correlation between results in group 1 and group 2. In summary, the performance results show that the ERSP is a little more effective in learning English by sector-university students.

However, it is difficult to argue that the form of content representation in educational resources (text or hypertext with multimedia) is a significant factor.

\section{Time}

As a next step, we can look at the time values. The learning time in self-work study was not restricted, 186 works were analysed in total. The results of participants in group 1 and group 2 are given in Table 6 .

Table 6

Time for learning during self-study work 2013-2017

\begin{tabular}{lllll}
\hline $\begin{array}{c}\text { Student } \\
\text { Group }\end{array}$ & \multicolumn{2}{c}{ Number of works } & \multicolumn{2}{c}{ Average time, hour } \\
\hline & $\begin{array}{c}\text { Knowledge- } \\
\text { oriented }\end{array}$ & $\begin{array}{c}\text { Skills- } \\
\text { oriented }\end{array}$ & $\begin{array}{c}\text { Knowledge- } \\
\text { oriented works }\end{array}$ & Skills-oriented works \\
\hline group 1 & 93 & 93 & $13 \mathrm{~min}$ & $38 \mathrm{~min}$ \\
\hline group 2 & 78 & 78 & $25 \mathrm{~min}$ & $69 \mathrm{~min}$ \\
\hline Total & 171 & 171 & & \\
\hline $\begin{array}{l}\text { Difference in } \\
\text { rates }\end{array}$ & & $12 \mathrm{~min}$ & $31 \mathrm{~min}$ \\
\hline
\end{tabular}

The results show that learning with the ERSP requires less time that learning with printed English course books. In case of group 2, students needed more than 0.3 hours for performing knowledge-based tasks, whereas in case of group 1 the students needed around 0.2 hours. As for skill-oriented tasks group 1 spent 0.6 hours, whereas group 2 spent 1.6 hours. Thus, learning with the ERSP required around 50\% less time compared to traditional way of learning. However, it is not a considerable and statistically significant difference. Because the critical value is 13.37 , while $\chi^{2}$ at significance level is 0.021 , which is $>0.05$.

Note that these results can be evaluated together with the results described concerning with the student performance tests. The smaller learning time for the ERSP can also be explained 
by no time spent on handwriting. In addition, we should say about time that instructors spent to check student self-study works. In case of teaching English with the ERSP, student works were check by a computer. On the other hand, test generation had remained manual and timeconsuming.

\section{Questionnaire}

At the questionnaire phase, the participants in group 1 were asked about their experience and make a list of advantages and disadvantages for the ERSP, where one participant could gave several characteristics. As shown in table 7, most students mentioned usability and sectororiented content of the ERSP among its advantages, little fewer students wrote about time and effort consuming.

Table 7

The ERSP advantages (93 participants)

\begin{tabular}{llc}
\hline No & Feature & Number of students \\
\hline 1 & Time consuming & 57 \\
\hline 2 & Usability & 81 \\
\hline 3 & Effort consuming & 58 \\
\hline 4 & Sector-oriented content & 78 \\
\hline
\end{tabular}

The ERSP disadvantages were about software failures and mistakes in tests due to their manual implementation into the programme shell.

Looking at the characteristics given by the participants, we can see that the ERSP is little different from other well-developed study packages for English learning. The only significant factor is the way to transfer knowledge (a printed text-book or a computer).

Thus, we cannot consider the ERSP to be an innovative instrument to make knowledge absorption by sector-university students more effective. It remains a question concerning a student's personal performance open: Is a form of knowledge representation in educational resources significant?

\section{Content representation format}

We proposed that a breakthrough can be made with ontology as a promising alternative to hypertext educational resources. What is of primary importance, both human and computers can 
understand it. Such a formal logical representation is a kind of universal form that is low dependent on a human way of thinking and national languages (Kuhn, 2014).

To answer the question about a preferable form for knowledge representation in sectororiented educational resources, a questionnaire survey among engineering and business students of three sector universities was conducted. In the questionnaire, we looked at the following dimensions: information perception, way of memorising and preferable content representation format.

The participants were asked what information they found easier to percept in their selfwork study. They could choose from four options: "linear text" (1), "graphical representation" (2), "combination of linear text and graphical representation with graphical representation predominance" (3) and "combination of linear text and graphical representation with linear text predominance". Figure 1 shows the choice of participants. Overall, the students preferred to have graphical aid in their learning materials. $57 \%$ of the students chose graphical representation or its combination with a linear text, whereas $43 \%$ of the respondents pointed out that linear text predominance was better for understanding.

Fig. 1: Distribution of answers about information perception.

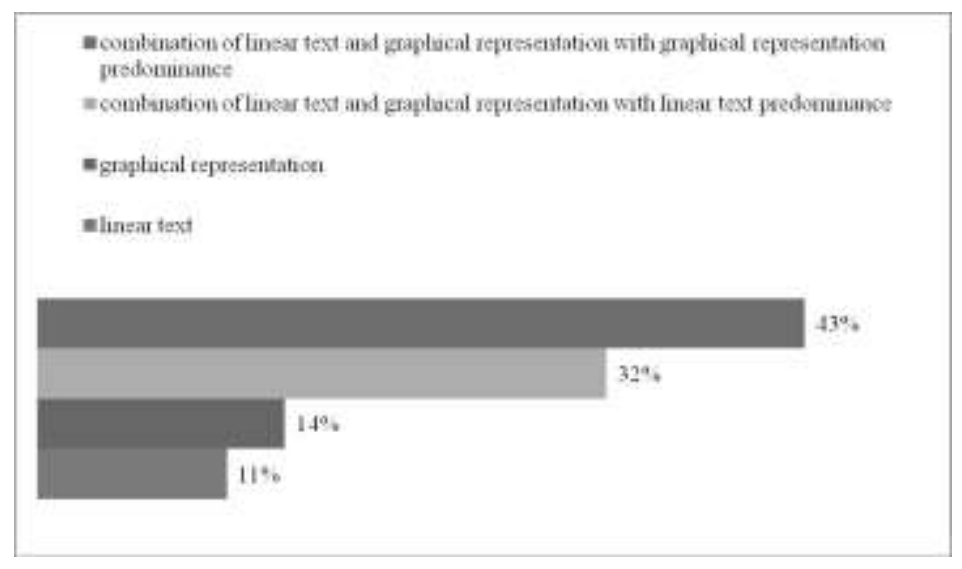

To understand how information perception influences the choice for educational resources format, the respondents could choose from the following four options: "paper-printed textbooks" (1), "Internet recourses" (2), "lecture notes" (3) and "slide-shows" (4). They could also write about other resources they used. Figure 2 presents that lecture notes and slide-shows were very popular answers (53\%), whereas text and hypertext resources had less score (42\%). Internet and slide-show files given students by their instructors were the most popular educational resources and paper printed textbooks turned to be the least popular. 
Fig. 2: Educational resources using by students in their self-work study.

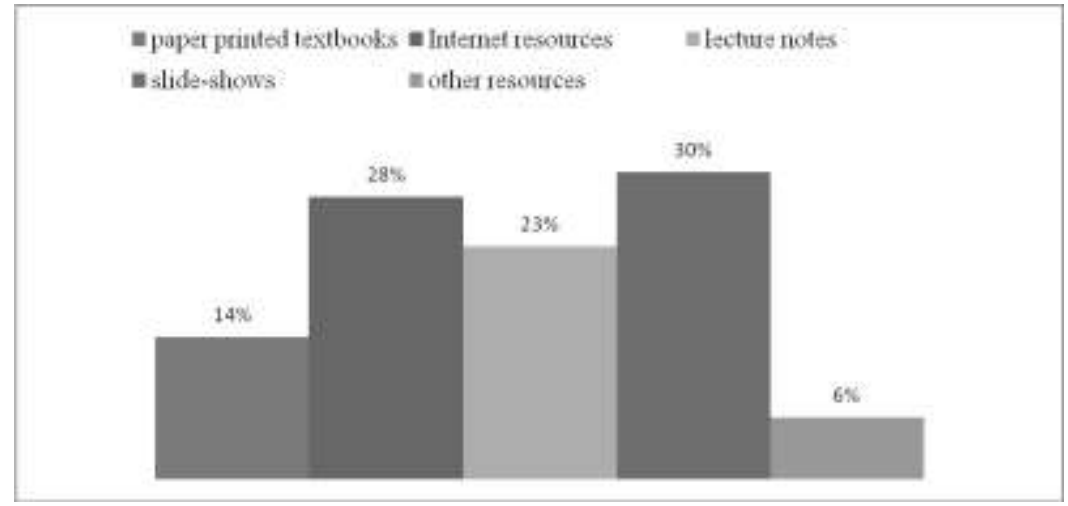

Figure 3 shows the choice of the participants about the way of memorising in learning. Here the students could choose from three options: "learning useful information by heart" (1), "structure new learning material" (2) and "copy out useful information from a textbook" (3). We do not have a convincing explanation for this distribution and it might be misunderstanding about the meaning of "memorising" by the students and the authors. Anyway, approximately $50 \%$ of the respondents tried to structure new learning material to memorise it.

Fig. 3. Distribution of answers about ways of memorising in learning by the students.

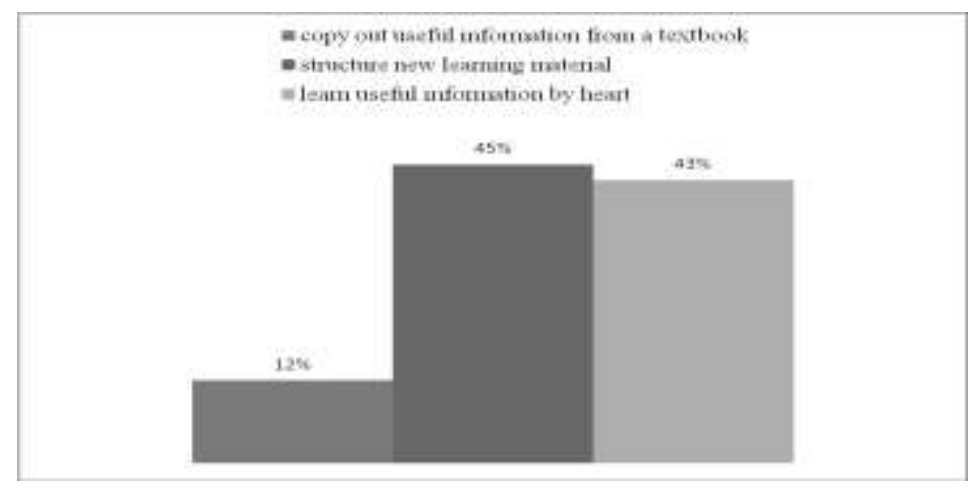

Thus, structured educational content seems to be better for perception and memorising. The students can do it on their own or receive from the instructors. This demonstrates that students of real sector universities prefer thinking on the system level and logically. The final question was about asking the participants which format of content representation they would prefer. The students were presented a structured text (a piece of ontology) and an ontograph. The ontograph framework was described in (Kuhn, 2010). 
We thought that there would be a difference in the answers of business and engineering students. However, Figure 4 shows little difference. The survey results indicate that the criterion $\chi^{2}$ is 7.395. So, critical value $\chi^{2}$ at significance level $\mathrm{p}<0.01$ is 105.07 . Thus, there is irrelevant correlation between the results.

Fig. 4. Distribution of answers about learning content representation formats throughout engineering and business students.

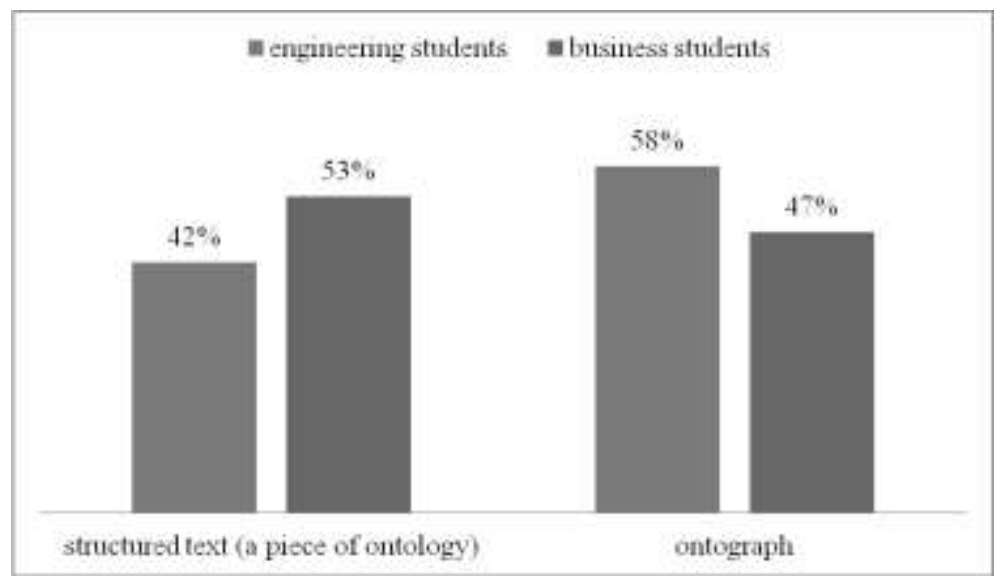

Due to there was a difference in the business and engineering students choice, we distributed their answers throughout the faculties. Figure 5 shows that we could not find a considerable difference in the data obtained. Overall, almost half of the participants chose a structured text, and rest of the participants chose an ontograph.

Fig. 5. Distribution of answers throughout faculties.

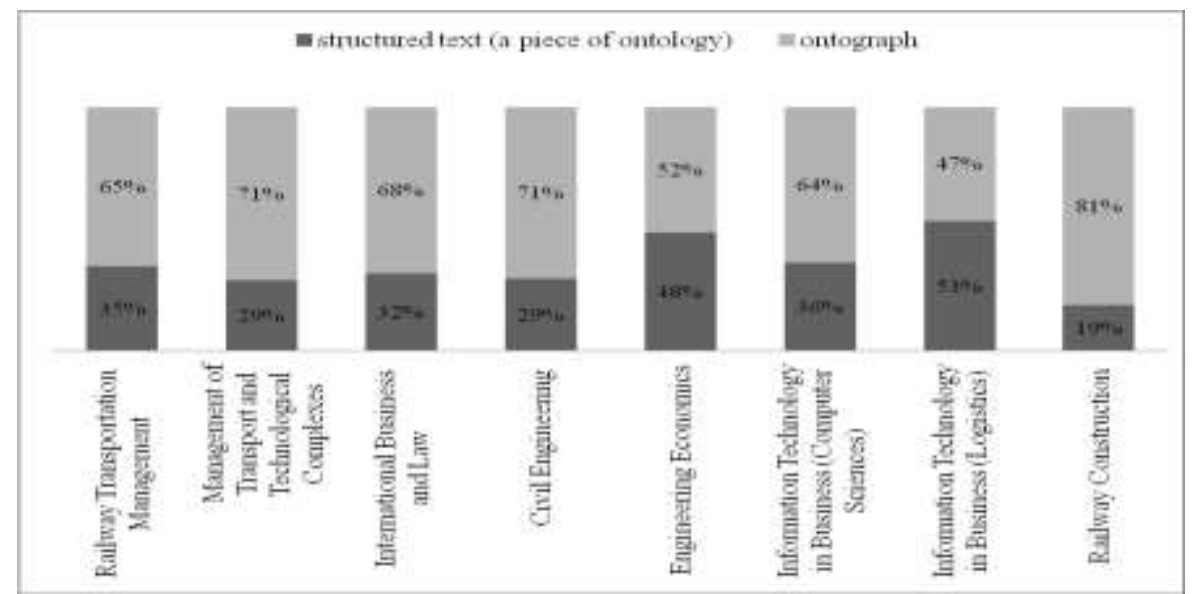

Significance

The charts with the experiment and survey results indicate no statistically significant values except time saving due to automation of self-learning process. The evaluation was done 
by using $\chi^{2}$ criterion, which is a non-parametric statistical method for testing the difference between measurements of a paired sample.

Evaluation

Finally, it can be evaluated what factors determine the gain of knowledge by sector university students. According to the results, we could say that either text or hypertext content representation format has no difference in gaining knowledge by students. The only significant factor was gaining time with the ERSP work. The evaluation of the test results has revealed that communicative competence level is gained at the same level by both ways - multimedia hypertext and text.

Furthermore, the results of survey show that the ERSP was noticed as a resource having usability and sector-oriented content also being time-consuming. It should be noted that there is no significant dependence between getting knowledge and applying knowledge in performing tasks.

The results of a questionnaire survey have shown that advantages for better knowledge absorption and their reproducibility in skills can be found in ontology. However, this needs further studies and a prototype of an ontology editor called Onto.plus has been developed in Siberian Transport University (Russia).

\section{Conclusion}

The knowledge-based approach predominated in Soviet professional education. In the post-Soviet period Russia's integration into the Global Educational Space required new approaches to learning and instructing sector university students, therefore the competency-based approach has replaced the conventional knowledge-based one. Due to transition to the Knowledge Economy and application of information technologies in almost all spheres of human activity, researches turned back to the issue of knowledge management within the competencybased approach via new information technology solutions and standards. The latest international web-standard for knowledge representation is ontology.

Many post-Soviet researches apply to a number of factors that can be significant to achieve educational results described in competences. Although there is a relation between these results and knowledge absorbed by university students, factors significant for effective knowledge absorption in the context of evolution of the approaches and Virtual Learning Environments have been still fuzzy. Issues specific for sector universities do not count as well. 
This explains the need to explore factors that are significant for absorption of knowledge by sector university students.

The results of the experiment demonstrate that a type of knowledge holder (a printed textbook or a programme module) is not significant. There is a poor dependence between knowledge and skills of students in the control and experimental groups. Thus, the performance results show that the ERSP is little more effective compared to a printed textbook. A student's major in sector universities is also not significant. Both engineering and business students prefer thinking systematically and logically. This is a reason to choose well-structured texts. At the same time, a focus of content on a particular industry is important. The reason is that industryspecific knowledge is reproduced in particular skills needed for profession problem solving. A way to transfer knowledge is another significant factor. Time saving due to automation of student self-study and its assessment by instructors has been stated during the experimental work. Whereas many students mentioned usability of the ERSP as its advantage, we can see no big difference between text or hypertext representation for knowledge digestion. The results of a questionnaire survey have shown that ontology can be a preferable form of knowledge representation in future.

We may consider knowledge management approach promising to learning and instructing sector university students. It stays within the competency-based approach but addresses the achievements of Soviet educators in meeting the challenge of knowledge absorption by students. Another advantage is applying to the international web standard of knowledge representation. All these unveil the didactic potential of ontologies for learning and instructing social academic disciplines in post-Soviet sector universities.

\section{Acknowledgements}

The ERSP development was supported by the grant of Siberian Transport University (Novosibirsk) (an Agreement No. 10, 28.05.2013).

Further study is conducted within the State Contract No. 30/16 dated May 31, 2016 signed between Training and Methodology Centre for Railway Transport (Moscow) and Siberian Transport University (Novosibirsk).

We appreciate the feedback we received from Igor Mitsuk, the Deputy Head of Federal Agency for Railway Transport, and we thank Professor Valeriy Khabarov, the Dean of 
Information Technologies in Business Faculty in Siberian Transport University for his scientific consulting. 


\section{References}

Adolf, V.A., Anjushin, S.V. \& Grishaev, S.V. (2011). Managing the development of professional training of a Humanities University alumnus within competitive business environment: monograph. Moscow: ATISO Publishing House.

Alexander, P.A. (2003). The development of expertise: The journey from acclimation to proficiency. Educational Researcher, 32(8), 10-14.

Alexander, P.A. \& Judy J.E. (1988). The interaction of domain-specific and strategic knowledge in academic performance. Review of Educational Research, 58, 375-405.

Andrianova, S.V. (2013). Ontology in English technical terminology learning. Philology and Linguistics, 5(68), 100-104.

Asoodar, M., Atai, M.R., Vaezi, Sh. \& Marandi, S.S. (2014). Examining effectiveness of communities of practice in online English for academic purposes (EAP) assessment in virtual class. Computers \& Education, (70), 291-300.

Bellucci, A. \& Pennacchio, L. (2016). University knowledge and firm innovation: evidence from European countries. Journal of Technology Transfer, 41, 730-752.

Bespalko, V.P. (1989). Summands of a pedagogical technology. Moscow: Pedagogy.

Bittman, B.L. \& Russell, W.B. (2016). Civic Education in United States: A Multiple Regression of Civic Education Scores from the National Assessment of Educational Progress. Research in Social Sciences and Technology, 1(2), 1-23.

URL: http://ressat.org/index.php/ressat/article/view/16/15

Bykadorova, E.S. \& Skibitsky, E.G. (2009). Information means as a pedagogical tool for preparation of competent graduates of transport higher schools. Siberian Pedagogical Journal, 3, 85-95.

Bykadorova, E.S., Volegzhanina, I.S. \& Chusovlyanova, S.V. (2014). Web 2.o tools perspectives at technical university when teaching a foreign language. In the World of Scientific Discoveries, 5.1(53), 299-308.

Chua, F.-F. \& Tay, E.-S. (2011). Developing Virtual Learning Environment 2.0 Using Web Services Approach. ICALT, 230-234.

Demirhan, G. \& Yücel, C. (2016). A prediction for teacher commitment: effects of managerial style, burnout and demographics, Research in Social Sciences and Technology, (I)1, 24-43. 
De Jong, T. \& Ferguson-Hessler, M.G.M. (1996). Types of qualities of knowledge. Educational Psychologist, 31(2), 105-113.

Diaz Redondo, R.P. (2012). Collaborative and role-play strategies in software engineering learning with Web 2.0 tools. Computer Applications in engineering Education, 2(44), 110 123.

Dorokhova, O.E. (2015). Semantic model competence in adaptive system for automated learning]. Modern Problems of Science and Education, 3, 434-543.

Edler, J. (2003). Knowledge Management in German Industry. Study in the Framework of an OECD Initiative of the Centre for Educational Research and Innovation (CERI) on behalf of the Donors' Association for the Advancement of Science in Germany (Stifterverband für die Deutsche Wissenschaft) with the support of the Federal Ministry for Education and Research (Bundesministerium für Bildung und Forschung/BMBF). Final report. Fraunhofer Institute for Systems and Innovation Research (ISI) Karlsruhe. URL: http://www.isi.fraunhofer.de/isiwAssets/docs/p/de/publikationen/KM_Study_ISI_OECD_Edler_final_report.pdf Eraut, M. (2004). Transfer of Knowledge between Education and Workplace Settings. In: Rainbird, Helen, Fuller, Alison and Munro, Anne (eds.) Workplace Learning in Context. Routledge, London \& NY, 201-221.

Ginecinskij, V.I. (1989). Knowledge as a category of pedagogics: an experience of pedagogical knowledge engineering. Leningrad: Leningrad University Press.

Girard, J.P. \& Girard, J. L. (2015). Defining knowledge management: Toward an applied compendium. Online Journal of Applied Knowledge Management 3(1):14, 1-20. URL: http://www.iiakm.org/ojakm/articles/2015/volume3_1/OJAKM_Volume3_1pp120.pdf

Grammes, T. \& Açıkalın, M. (2016). Qualitative Data Collection and Interpretation: A Turkish Social Studies Lesson. Journal of Social Studies Education research, 7(1), 1-40.

Guillou, C. (2007) The corporate knowledge power for decision support systems. Institut für Algorithmen und Kognitive Systeme Universität Karlsruhe (TH) SS. URL: http://crypto.iti.kit.edu/fileadmin/User/calmet/stdip/DA-Guillou.pdf Gupta, J. \& Sushil, Sh. (2004). Creating Knowledge Based Organizations. Boston: Idea Group Publishing. 
Hornos, M.J., Hurtado, M.V., Fernández-Sánchez, M.P., López-Martínez, Á., Benghazi, K., Rodríguez-Almendros, M.L. \& Abad-Grau, M.M. (2012). Hierarchical Role-based Design of Web-based Educational Systems for Blended Learning in Higher Education. Journal of Research and Practice in Information Technology, (2), 223-243.

Hussain, F. (2013). E-Learning 3.0 = E-Learning 2.0 + Web 3.0?. 3(3), IOSR Journal of Research \& Method in Education (IOSR-JRME), 39-47.

Introduction to Knowledge Management. University of North Carolina at Chapel Hill. (2007). URL: www.unc.edu

ISO/IEC 20016-1:2014 Information technology for learning, education and training - Language accessibility and human interface equivalencies (HIEs) in e-learning applications - Part 1: Framework and reference model for semantic interoperability. URL: https://www.iso.org/standard/50963.html

Ivanova, E.O. (2007). Competency approach vs knowledge-based and cultural approach approaches. Internet-journal “Jejdos”. URL: http://www.eidos.ru/journal/2007/093023.htm (June 26, 2017).

Jung, Yu. (2013). Development of virtual worlds in agriculture and natural resources for simulation experiments and e-learning using ontology-based simulation. ProQuest Dissertations \& Theses A \& I.

Kilinç, E., Kilinç, S., Kaya, M., Başer, E., Türküresin, H., \& Kesten, A. (2016). Teachers’ attitudes toward the use of technology in social studies teaching. Research in Social Sciences and Technology, 1(1), 59-76.

Kudinov,V.A. (2010). Model of educational field on the bases of technology of knowledge management. RUDN Herald. Series: Educational Information, (1), 81-85.

Kuhn, T. (2010). An Evaluation Framework for Controlled Natural Languages in Proceedings of the Workshop on Controlled Natural Language (CNL 2009). URL: http://link.springer.com/chapter/10.1007/978-3-642-14418-9_1\#page-1

Kuhn, T. (2014). A Survey and Classification of Controlled Natural Languages. Computational Linguistics, 1(40), 121-171.

Kybartaite, A., Nousiainen, J. \& Malmivuo, J. (2010). Technologies and methods in virtual campus for improving learning process. Computer Applications in Engineering Education, 21(1), 185-192. 
Leisyte, L. \& Horta, H. (2011). Introduction to a special issue: Academic knowledge production, diffusion and commercialization: policies, practices and perspectives. Science and Public Policy, 38(6), 422-424.

Lishilin, M.V., Belov, M.A., Tokareva, N.A. \& Sorokin, A.V. (2015). Conceptual model of knowledge management system for forming professional competence in the field of IT in a virtual computer lab. Fundamental Research, 11(part 5), 886-890.

Mitsuk, I.V., Khabarov, V.I. \& Volegzhanina, I.S. (2016). Sector-related knowledge management in the "sector - sector educational establishment" system. Educational Technologies and Society, 3, 473-491.

Industry sector knowledge (core competency). (2015). National Research Council Canada. URL: http://www.nrc-

cnrc.gc.ca/eng/careers/behavioural_competencies/mg_industry_sector_knowledge.html

Nurminskij, I.I. \& Gladysheva, N.K. (1991). Statistic patterns of formation of knowledge and skills of students. Moscow: Pedagogy.

Pathirage, C.P., Amaratunga, R.D.G. \& Haigh, R.P. (2008). The role of tacit knowledge in the construction industry: towards a definition. CIB W89 International Conference on Building Education and research (BEAR), 11th - 15th February, Sri Lanka.

Poljakova, A.V. (1978). Knowledge absorption and development of schoolchildren. Moscow: Pedagogy.

Sim, W.W. (2015). Applying persona concept and ontology-based approach to support the requirements engineering process. ProQuest Dissertations \& Theses A \& I.

Tarman, B. (2016). Innovation and education. Research in Social Sciences and Technology, (1)1, 77-97.

Tarman, B. \& Acun, I. (2010). Social Studies Education and a New Social Studies Movement. Journal of Social Studies Education Research, I (1), 1-16.

Uzun, L. (2012). The Internet and computer-mediated artefacts for foreign language learning and practice, and intercultural communication: MOODLE, Second Life, and others. Procedia Social and Behavioral Sciences, 46, 3296-3300.

Varga, A. \& Parag, A. (2009). Academic knowledge transfers and structure of international research networks. Universities, Knowledge Transfer and Regional Development: Geography, Entrepreneurship and Policy. Edward Elgar, Cheltenham. 
Volegzhanina, I.S. (2016). Formation of a sector-related knowledge definition. Problems and tendecies of higher education development in Russia and abroad. In: Nagornova, A.Yu. (ed.). Ulyanovsk: Zebra Publishing, 6-20.

Volegzhanina, I.S. \& Chusovlyanova, S.V. (2016). English for Railways. Part I. Railway Track and Railway Structures. Digital resource, certificate of registration No. 21720 dated 22.03.2016, Novosibirsk.

Zeleny, M. (2006). Knowledge-information autopoietic cycle: towards the wisdom systems. International Journal of Management and Decision Making, 1, 3-18.

Xiao, Zh.-x. (2017). The impacts of trust relationship on knowledge absorptive capacity: an empirical study from service outsourcing enterprises. Proceedings of the 23rd International Conference on Industrial Engineering Management 2016. Ed. Ershi Qi,Jiang Shen, Runliang Dou. Tianjin University. Atlantis Press, 81-86.

Wright, S. (2015). Universities in the knowledge economy: mapping, managing, gendering and contesting boundaries in the new university-industrial complex. Universities in the Knowledge Economy -Transforming Higher Education in the Asia-Pacific Rim and Europe. International conference, University of Auckland, 10-13 February 2015, 6. URL: https://cdn.auckland.ac.nz/assets/arts/documents/UNIKE_abstracts.pdf 